\title{
Efficient Desalination of Brackish Ground Water via a Novel Capacitive Deionization Cell Using Nanoporous Activated Carbon Cloth Electrodes
}

\author{
K. Laxmana,b, M.T.Z Myinta, M. Al Abric, L. Al-Gharibia, B. Al Namania, H. Bourdoucen ${ }^{\mathrm{b}, \mathrm{d}}$ and \\ J. Dutta*a \\ ${ }^{*}$ Chair in Nanotechnology, Water Research Center, Sultan Qaboos University, POB. 17, Muscat, PC 123, Oman \\ ${ }^{b}$ Department of Electrical and Computer Engineering, Sultan Qaboos University, POB. 33, Muscat, PC 123, Oman \\ cDepartment of Petroleum and Chemical Engineering, Sultan Qaboos University, POB. 33, Muscat, PC 123, Oman \\ ${ }^{d}$ Communication and Information Research Center (CIRC), Sultan Qaboos University, POB. 17, Muscat, Oman
}

Received 24 September 2014; Accepted 18 March 2015

\begin{abstract}
Sea water intrusion in ground water sources has made brackish water desalination a necessity in Oman. The application of capacitive deionization (CDI) for the deionization of ground water samples from wells in Al-Musanaah Wilayat is proposed and demonstrated. A CDI cell is fabricated using nanoporous activated carbon cloth (ACC) as the electrodes and is shown to be power efficient for desalting ground water samples with total dissolved solids (TDS) of up to $4,000 \mathrm{mg} / 1$. The CDI cell was able to remove up to $73 \%$ of the ionic scaling and fouling contaminants from brackish water samples. The power consumption for deionization of brackish water was estimated to be $1 \mathrm{kWh} / \mathrm{m}^{3}$ of desalinated water, which is much lower than the power required to process water with equivalent TDS by the reverse osmosis processes. The CDI process is elaborated, and observations and analysis of the ion adsorption characteristics and electrical properties of the capacitive cell are elucidated.
\end{abstract}

Keywords: Capacitive deionization, Activated carbon cloth, Brackish water desalination.

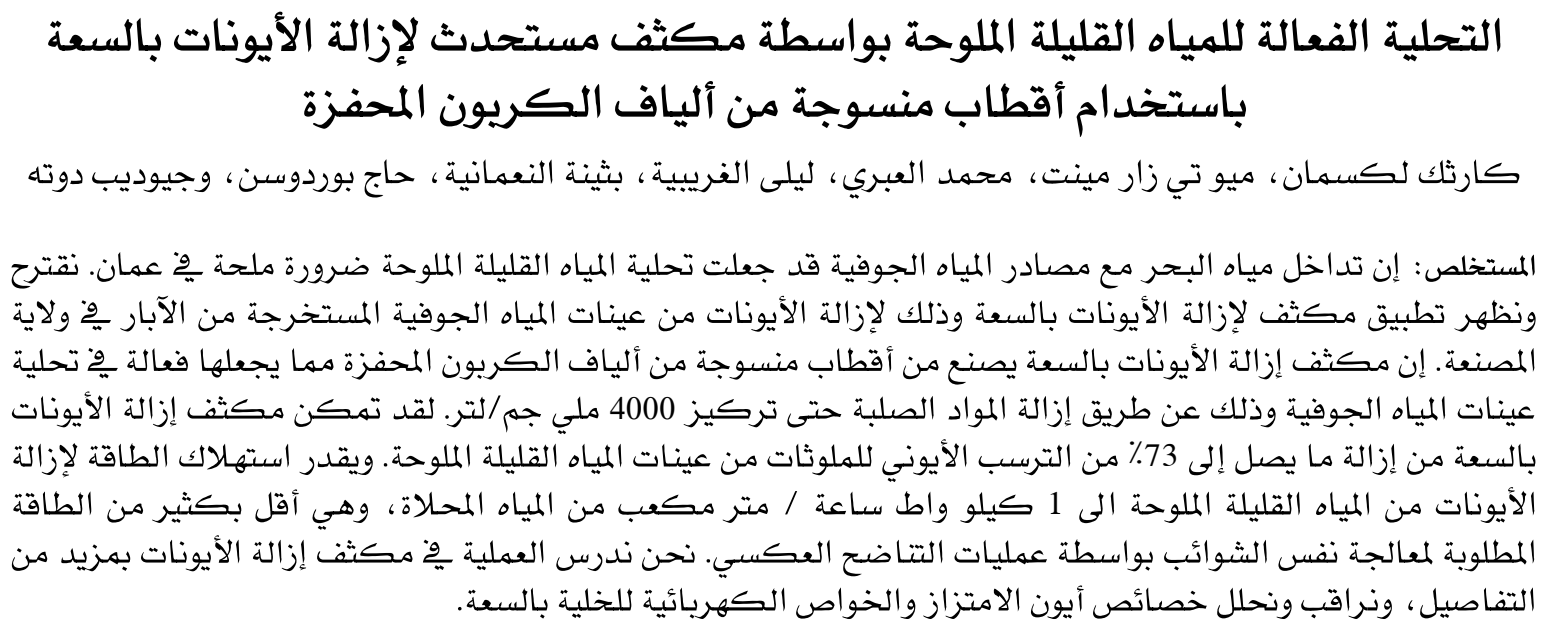




\section{Introduction}

Seawater intrusion into ground water sources is a major problem in coastal regions worldwide. Groundwater is the primary source of fresh water for more than two-thirds of the world's population living in these regions. Particularly in the Sultanate of Oman, which has more than 2,000 kilometers of coastline, rapid population growth and increased agricultural activities have severely stressed groundwater sources, which constitutes about $65 \%$ of available fresh water in the Sultanate. Increased demand for groundwater (1,650 $\mathrm{Mm}^{3} /$ annum) compounded by falling water tables has led to rapid sea water intrusion, costing the Sultanate an estimated US\$19-36 million annually $(2012 ; 2006)$. To supplement the groundwater supply, the government has prioritized water desalination, enabling it to grow from $3 \%$ of the total water supply in 1999 to $13 \%$ in 2008 (Gastli et al. 2010). Although reverse osmosis (RO), with its modular technology, is at the forefront of this industry, the membranes used in $\mathrm{RO}$ are generally prone to fouling by dissolved macromolecular organic substances, soluble inorganic compounds, and suspended particles and microorganisms, leading to reduction in water recovery and membrane life (Van Der Bruggen et al. 2002; Vrouwenvelder et al. 2003).

Generally, extensive pretreatment like coagulation, flocculation, $\mathrm{pH}$ adjustment, and the addition of antiscalants, disinfectants, and media filtration are required to increase water recovery, which further increases operational costs of RO plants (Ghabayen et al. 2004; Hassan et al. 1998). Typically, RO plants desalinating brackish water can remove $98 \%$ of the salt at total dissolved solid (TDS) levels of 2,500-3000 mg/L, using pressures of 13.617 atmospheric pressure (atm) and a flux of 24 $\mathrm{L} / \mathrm{m}^{2} /$ day. Recent technological advancements like high efficiency pumps and energy recovery systems have reduced the expected energy requirements of brackish water $\mathrm{RO}$ to $\sim 2-3 \mathrm{kWh} / \mathrm{m}^{3}$ (Zhao et al. 2013). However, the $\mathrm{RO}$ process is restricted to certain operating conditions, including maximum temperatures of $45^{\circ} \mathrm{C}, \mathrm{pH}$ values of $2-10$, a silt density index $(\mathrm{SDI})<3$, and mandatory dechlorination, amongst others. This makes changes due to variations in water quality uneconomical in operational RO plants (Nicolaisen, 2002). Additionally, water recovery in $\mathrm{RO}$ is governed by the scale formation potential of brackish water, which is rich in scaling elements including calcium carbonate, calcium sulfate, magnesium sulfate, strontium sulfate, silicates, and aluminosilicates (Amiri and Samiei 2007; Antony et al. 2011; Farhat et al. 2012; Ghafour 2003; Tzotzi et al. 2007). Scaling reduces productivity and the water recovery ratio, which are necessary to maximize water production due to restrictions on brine reinjection in Oman (Ahmed et al. 2001; Mohamed et al. 2005).

An alternative and emerging desalting technique which can circumvent these issues is called capacitive deionization (CDI), wherein emphasis is laid on removing salt from the water rather than separating the water from the salt as is done in RO (Porada et al. 2013; Zhao et al. 2010). Since the volume fraction of salt is considerably lower than the volume of water in ground or sea water, the process has shown promise as a good alternative to $\mathrm{RO}$, especially for brackish water deionization (Lee et al. 2006; Mossad et al. 2013; Mossad and Zou 2013; Zhang et al. 2013). Salt removal by CDI involves the electrosorption (potential induced ion adsorption) of ions on electrodes and can be reasonably fitted with the Langmuir adsorption isotherm (Mossad et al. 2013; Ryoo et al. 2003; Welgemoed and Schutte, 2005) and modified Donnan model, where equilibrium achieved between the adsorption and desorption of ions defines the salt adsorption capacity of the electrodes. Since ion adsorption takes place on the surface of the electrodes, desalting efficiency is directly proportional to the surface area of the electrodes (Zhao et al. 2010). The magnitude of the applied potential for CDI is generally kept below $2.0 \mathrm{~V}$ DC to avoid hydrolysis of the aqueous media (Biesheuvel et al. 2009; Oren 2008).

In a CDI cell, one electrode is connected to the positive potential terminal and the other to the negative terminal of the DC power supply. When salt water is passed through the cell, anions (negative ions) will be electrosorbed to the positive terminal while cations (positive ions) will be electrosorbed to the negative terminal, thus depleting the water of ions and leading to desalted water at the output. Since the adsorption is a surface related phenomenon, continuous deionization leads to saturation of the electrodes and subsequent inability to adsorb any further. To circumvent this problem, every deionization cycle is followed by a regeneration cycle, during which the applied potential is removed, leading to a release of the electrosorbed ions from the activated carbon cloth (ACC) surface into the flowing solution, leading to a highly concentrated solution, known as brine, at the output. A key advantage of electrosorption is that the ions are 
a

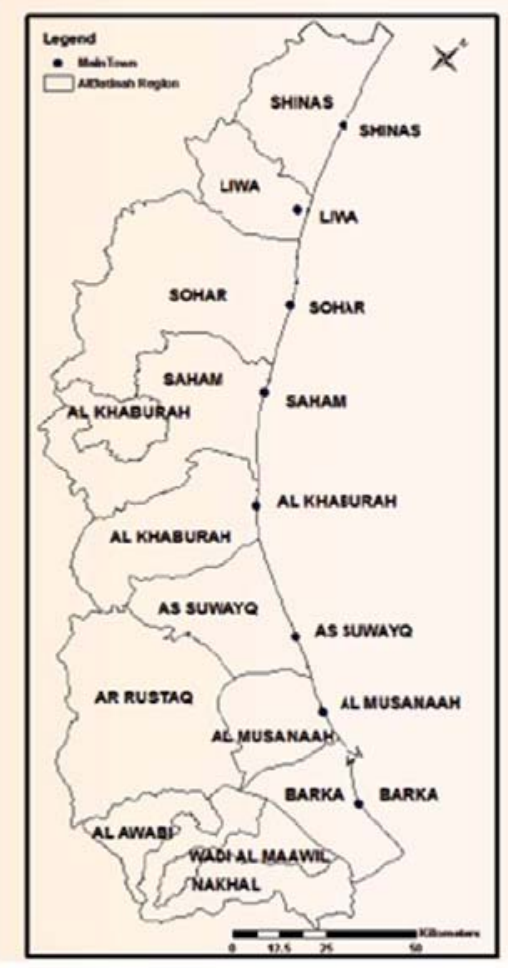

b

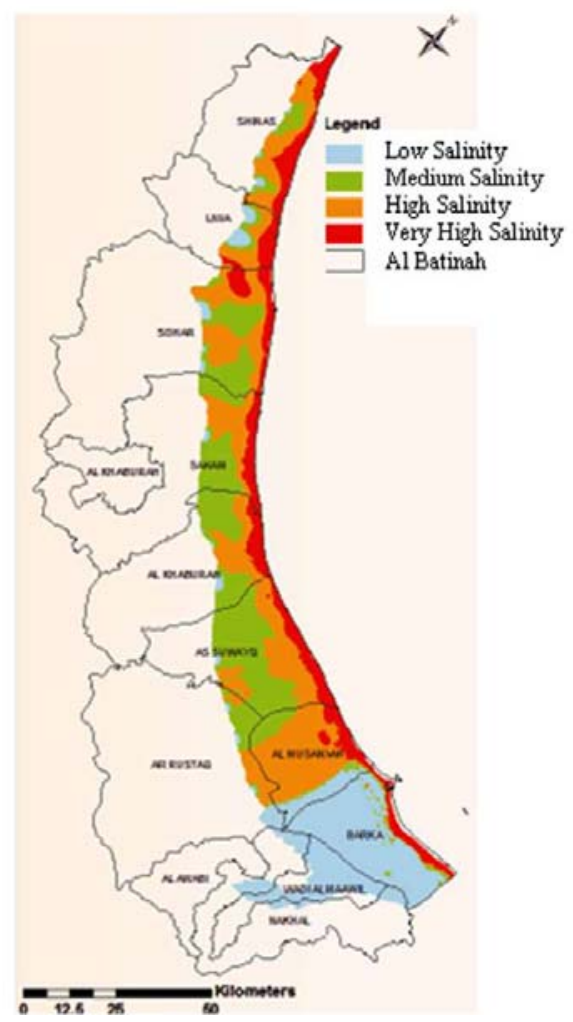

Figure 1. (a) Location of the Al Batinah Region, which accounts for more than $50 \%$ of Oman's agriculture production and (b) Salinity increase due to sea water intrusion in the Al Batinah region over the years (Ministry of Agriculture and Fisheries, 2012).

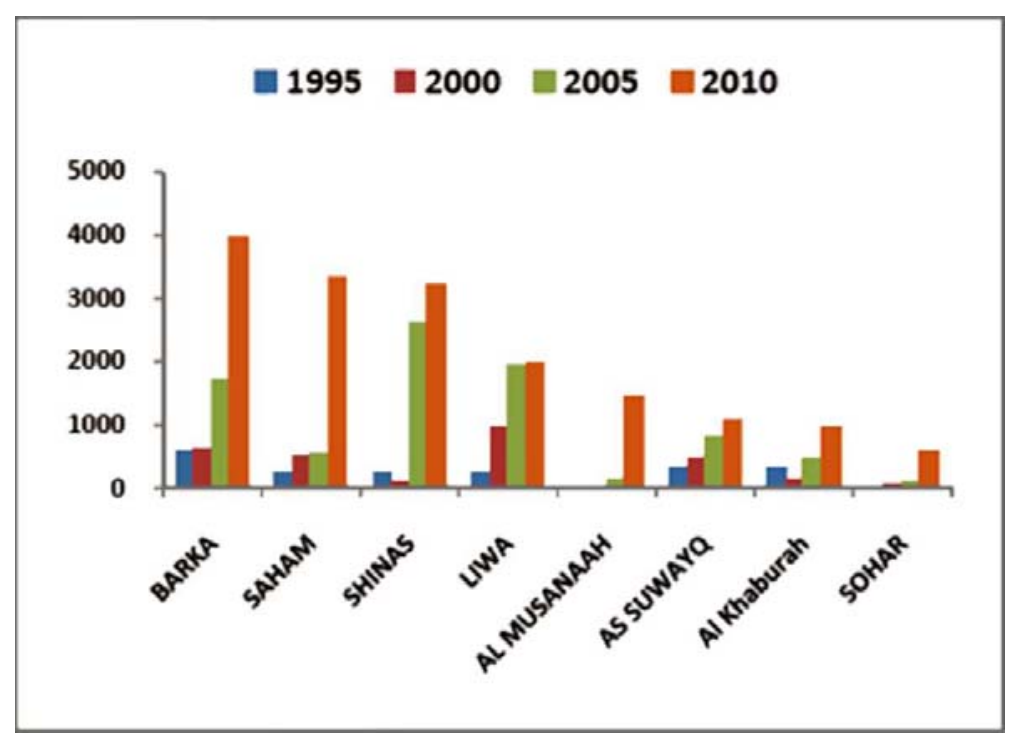

Figure 2. Representation of total land area affected by sea water intrusion showing that Al-Musanaah was heavily intruded (Ministry of Agriculture and Fisheries, 2012). 
physisorbed onto the electrode surface, minimizing electrode fouling and leading to longer operational life of the electrodes. Further, the absence of ion exchange membranes and the chemically inert nature of ACC enables the facile removal of any organic or microbial contamination without adversely affecting the electrode integrity by washing in an acid bath (Laxman et al. 2015; Mossad et al. 2013).

This manuscript demonstrates the use of CDI incorporated with ACC electrodes for efficient removal of salt from brackish water collected from wells in Al-Musanaah Wilayat in Oman. Emphasis is laid on the effect of an ionic charge on desalting capacity along with power consumed for the deionization of a well water sample to drinking water standards.

\section{Methods}

Analytical grade hydrochloric acid 34\% ( $\mathrm{HCl})$ (Merck KGaG, Darmstadt, Germany) was used without any further purification. FM-100 ACC Zorflex (Calgon Carbon Corporation, Pittsburgh, Pennsylvania, USA) with a mean pore diameter of $0.7 \mathrm{~nm}$ and a total pore volume of $1.417 \mathrm{~cm}^{3} / \mathrm{g}$ was used. Micropores accounted for $0.56 \mathrm{~cm}^{3} / \mathrm{g}$ and macropores for $0.85 \mathrm{~cm}^{3} / \mathrm{g}$, while mesopores were very few $\left(<0.001 \mathrm{~cm}^{3} / \mathrm{g}\right)$, making the material predominantly microporous. The ACC also possesses a ribbed surface with a hierarchical pore structure which reduced the pressure drop across the electrode and is preferable for flow systems like CDI. Nuclear magnetic resonance measurements estimated the surface area of pristine ACC to be $\sim 1000 \mathrm{~m}^{2} / \mathrm{g}$. In addition to the high surface area, previous reports have suggested that the sheet resistance of symmetrically cut ACC varies between $4-5 \Omega / \mathrm{sq} \mathrm{cm}$, all of which make it suitable for application in CDI (Subrenat et al. 2001). The electrode substrates (Brasquet and Le Cloirec 1999; Shim et al. 2001) were cleaned with highly concentrated $2 \mathrm{M} \mathrm{HCl}$ and heated to $115^{\circ} \mathrm{C}$, which is slightly above the boiling point of $\mathrm{HCl}$ solution, for 12 hours to remove mineral contaminants. Subsequently, samples were thoroughly rinsed with deionized water, dried in a vacuum oven at $150^{\circ} \mathrm{C}$ for 12 hours, and stored in a desiccator until needed for further use.

The CDI device (cell) used for the deionization consisted of two $10 \times 10 \mathrm{~cm}$ ACC electrodes separated by a spacer having a thickness of $650 \mu \mathrm{m}$. It was comprised of a reservoir made up of polymethyl methacrylate (PMMA) from the SYLGARD® 184 silicone elastomer kit (Dow Corning, Midland, Michigan, USA), a current collector (graphite electrode), and an acrylic plate to support the CDI cell [Figs. 3a-b].

For brackish ground water deionization, well water from two different wells located in $\mathrm{Al}$ Musanaah of the Al Batinah Region in Oman's northwest was chosen. The Al Batinah region as a whole accounts for $50 \%$ of the country's agricultural production, and $95 \%$ of the abstracted water in the governorate is used for agriculture and livestock. However, this area has experienced a steep increase in groundwater salinity due to a high abstraction rate and seawater intrusion [Figs. 1a and b; Fig. 2]. Of Al Musanaah's farms, $40 \%$ are irrigated with 2-5 $\mathrm{mS} / \mathrm{cm}$ brackish water, while only $35 \%$ are irrigated with $<2 \mathrm{mS} / \mathrm{cm}$ of ground water (2012).

The surface morphology of ACC electrodes was studied with a JSM-7200 field emission scanning electron microscope (FESEM) working at $20 \mathrm{kV}$ (JEOL USA, Inc., Peabody, Massachusetts, USA). Water conductivity was determined using EUTECH CON 700 conductivity probe with a cell volume of 5 $\mathrm{ml}$ (Thermo Fisher Scientific, Inc., Waltham, Massachusetts, USA) which was modified for online real time recording. Active surface area measurements were conducted using a nuclear magnetic resonance (NMR) relaxation technique in XigoNanotools equipment (Bethlehem, Pennsylvania, USA) with water as the solvent. The changes in the $\mathrm{T} 2$ relaxation time after perturbation was measured and analyzed by Acorn Area software (XigoNanotools) to interpret the surface area of the electrode using the specific surface relaxivity of activated carbon in contact with the solvent. Cations were determined by inductively coupled plasma optical emission spectrometer (ICPOES) 710 (Varian, Medical Systems, Palo Alto, California, USA). Power consumption was calculated by integrating the charging current decay curve in Matlab (Mathworks, Natick, Massachusetts, USA) to obtain the total charge deposited in one cycle. The charge deposited was multiplied by the applied voltage to obtain the work done in joules, which was subsequently converted to watts by dividing it by the duration of the deionization cycle. Rates of ion adsorption were obtained by fitting the ion adsorption rates (with respect to time and number of deionization cycles) as obtained by ICP with a cubic polynomial function with an $\mathrm{R}^{2}$ value greater than $99 \%$, followed by taking the first derivative of the cubic fitting function. 

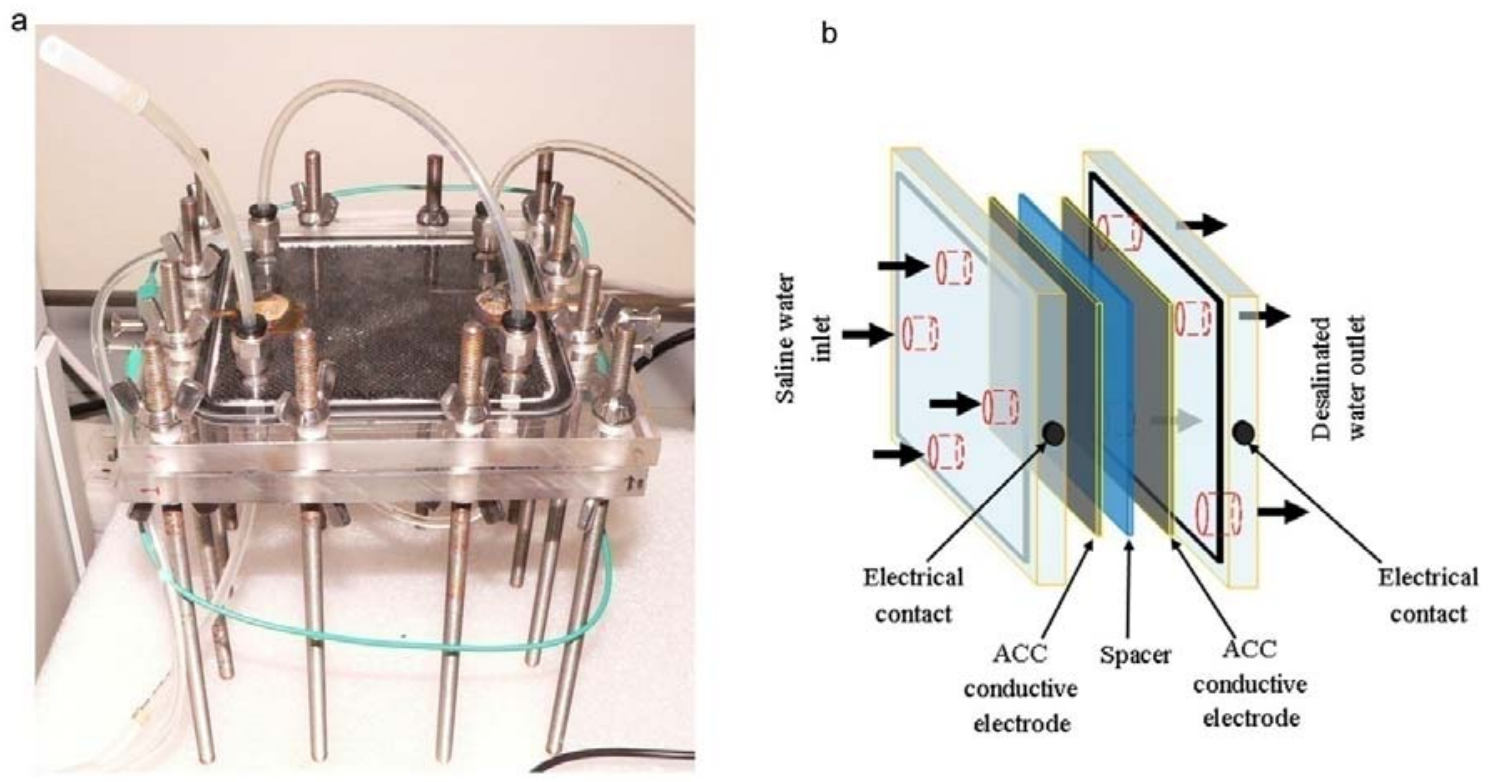

Figure 3(a). Prototype of the CDI cell comprising two $100 \mathrm{~cm}^{2}$ ACC electrodes separated by a spacer and (b) building blocks of the CDI cell showing the placement of the electrodes, spacer and electrical contacts.

\section{Capacitive Deionization Experiments}

The deionization/regeneration experiments were conducted using flow through capacitive deionization cell. Capacitive deionization experiments were performed in a batch mode, where $50 \mathrm{ml}$ of feed solution was passed through the cell at a flow rate of $5 \mathrm{ml} /$ minute in a continuous loop for 15 minutes. A peristaltic pump drive 5201 (Heidolph Instruments, Schwabach, Germany) was used to maintain a constant flow rate of the feed water into the CDI cell. During this period, a DC potential of 1.6 V DC was applied across the CDI electrodes, leading to electrosorption of the ions on the ACC electrodes [Fig. 4a]. Water samples were collected every five minutes during the deionization period to measure the ion content using ICP-OES. The change in solution conductivity, current and voltage across the cell was monitored using GW Instek GDM-396 online multimeters (Good Will Instrument Co., Taipei, Taiwan) for power consumption analysis. After 15 minutes of deionization, regeneration was carried out by removing the applied potential across the electrodes and letting the previously desalinated water flow through the system at five $\mathrm{ml} /$ minute.

During this period, ions which were previously electrosorbed onto the electrode surface were released and removed from the cell [Fig 4b]. The regeneration cycle was continued until original feed water feed water conductivity was recovered, confirming complete regeneration of the electrodes.

In a second experiment, the above deionization period of 15 minutes was followed by a regeneration period of 20 minutes to complete one deionization-regeneration cycle. A total of seven such cycles were conducted on water from well two to attain water fit for drinking. Water samples were collected after every cycle to measure the ion content and adsorption characteristics at different cycles.

\section{Results and Discussion}

A FESEM image shows the interwoven fiber structure of the conductivity of the ACC electrodes [Fig. 5] used for the deionization process. Each fiber is composed of macro, meso, and micropores, which lead to a highly active surface area available for ion adsorption (García-Quismondo et al. 2013; Huang et al. 2013). The deionization performance of the CDI cell was studied with ground water samples from two different wells in Al-Musanaah. The analyzed composition and properties of the as received well water samples are given in Table 1. 

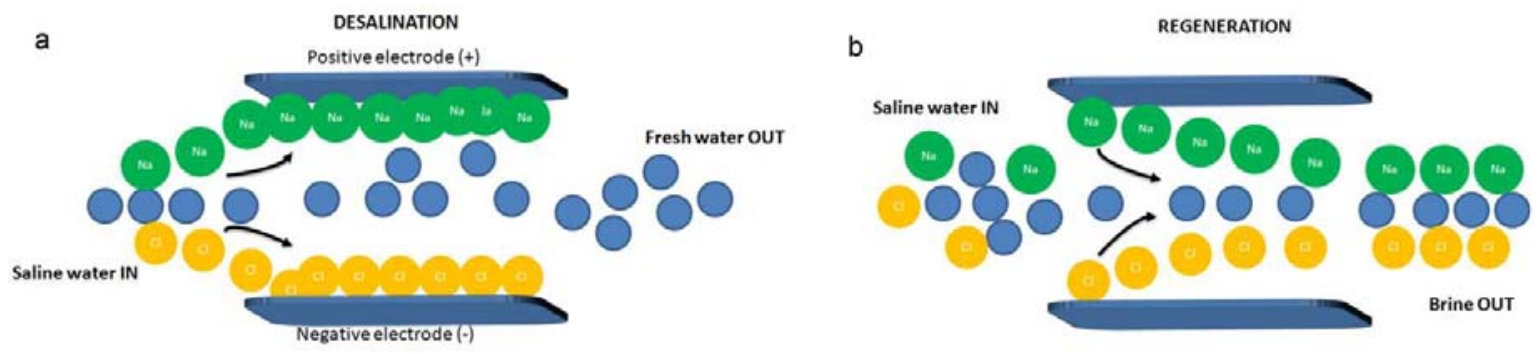

Figure 4. Schematic showing the functioning of a capacitive desalination cell where (a) the desalination step involves the application of a $1.6 \mathrm{~V} \mathrm{DC}$ potential across the electrodes and the subsequent electro-sorption of ions from the inlet feed water on to the ACC electrode surface and (b) is followed by the regeneration step wherein the surface adsorbed ions are released to the inlet water feed by removing the applied potential to regenerate the electrode surface prior to the next desalination step.

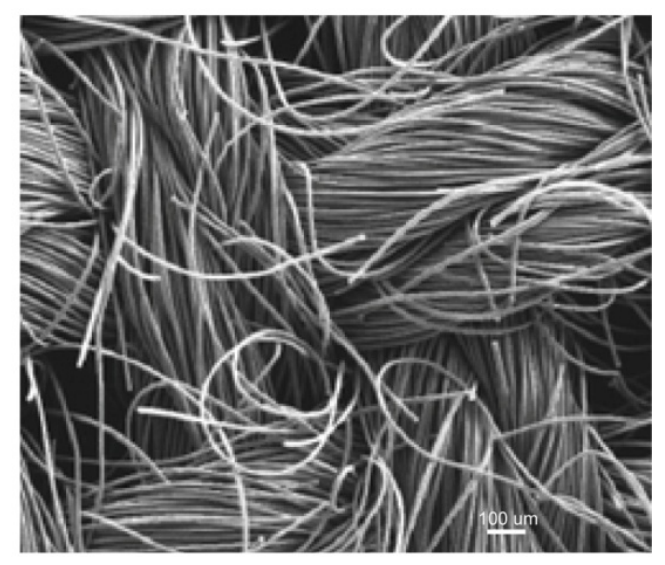

Figure 5. Field emission scanning electron microscopy image of activated carbon cloth (ACC) showing the inter-woven fibers.

Table 1. Measurements of properties of ground water samples from two wells in Al-Musanaah.

\begin{tabular}{|c|c|c|c|c|c|c|}
\hline Sample & $\begin{array}{l}\text { Conductivity } \\
(\mathrm{mS} / \mathrm{cm})\end{array}$ & $\mathrm{pH}$ & $\begin{array}{c}\text { Sodium } \\
\text { (Na) } \\
\text { (ppm) }\end{array}$ & $\begin{array}{c}\text { Calcium (Ca) } \\
(\mathrm{ppm})\end{array}$ & $\begin{array}{l}\text { Potassium (K) } \\
\quad(\mathrm{ppm})\end{array}$ & $\begin{array}{c}\text { Chloride } \\
\text { (Cl) } \\
(\mathrm{ppm}) \\
\end{array}$ \\
\hline Well 1 & 5.5 & 8.2 & 293 & 330 & 10 & 784 \\
\hline Well 2 & 3.1 & 8.0 & 252 & 244 & 8 & 507 \\
\hline
\end{tabular}

Table 2. Cation removal efficiency in the CDI cell for water from well one after a 15-minute deionization cycle as determined from inductively coupled plasma measurements. The conductivity of the water reduced from $5.5 \mathrm{mS} / \mathrm{cm}$ to $3.6 \mathrm{mS} / \mathrm{cm}$.

\begin{tabular}{cccc}
\hline Ion type & $\begin{array}{c}\text { Initial concentration } \\
(\mathbf{p p m})\end{array}$ & $\begin{array}{c}\text { Final concentration } \\
(\mathbf{p p m})\end{array}$ & \% Removal \\
\hline Sodium $\left(\mathrm{Na}^{+}\right)$ & 293 & 190 & 35 \\
Calcium $\left(\mathrm{Ca}^{2+}\right)$ & 330 & 184 & 44 \\
Potassium $\left(\mathrm{K}^{+}\right)$ & 10 & 7.7 & 23 \\
\hline
\end{tabular}


Table 3. Cation removal efficiency in the CDI cell for water from well two after 7 deionization cycles as determined from inductively coupled plasma measurements. The conductivity of the water was reduced from $3.2 \mathrm{mS} / \mathrm{cm}$ to $0.84 \mathrm{mS} / \mathrm{cm}$.

\begin{tabular}{cccc}
\hline Ion type & $\begin{array}{c}\text { Initial concentration } \\
(\mathbf{p p m})\end{array}$ & $\begin{array}{c}\text { Final concentration } \\
(\mathbf{p p m})\end{array}$ & \% Removal \\
\hline Sodium $\left(\mathrm{Na}^{+}\right)$ & 252 & 39 & 85 \\
Calcium $\left(\mathrm{Ca}^{2+}\right)$ & 242 & 35 & 86 \\
Potassium $\left(\mathrm{K}^{+}\right)$ & 8 & 3 & 63 \\
\hline
\end{tabular}
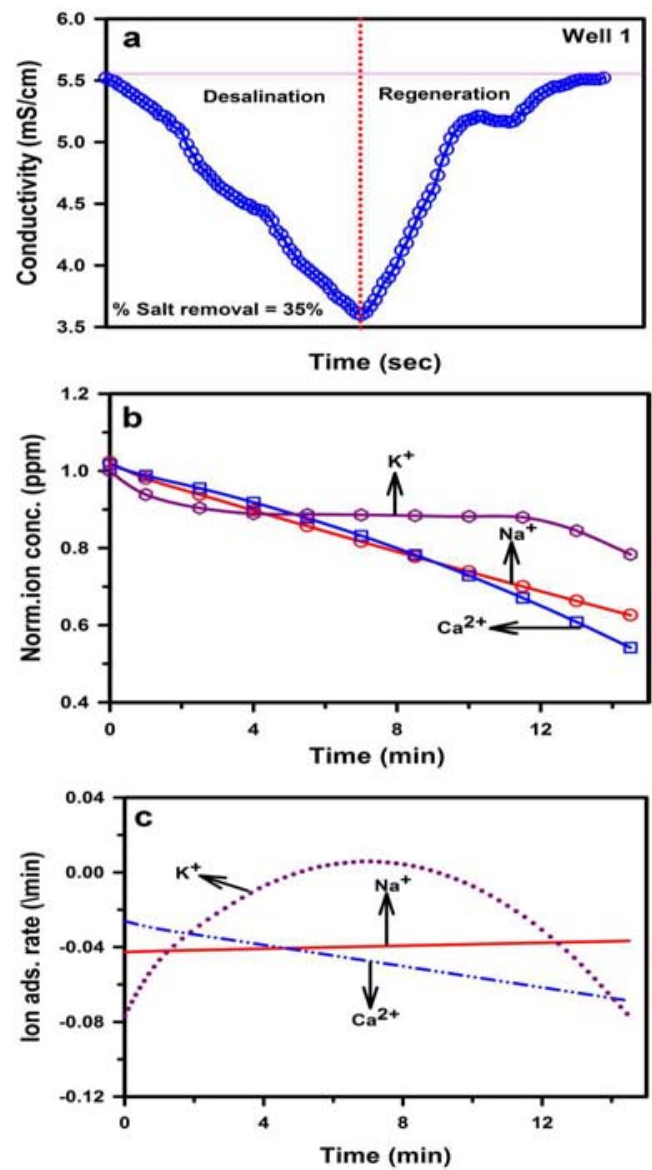

Figure 6. (a) Desalination and regeneration performance of a batch mode process for water from well 1, showing $35 \%$ overall salt removal efficiency. The desalination was carried at a flow rate of $5 \mathrm{ml} / \mathrm{min}$ for 15 minutes at an applied potential of 1.6 V DC; (b) normalized ion adsorption curve for sodium $\left(\mathrm{Na}^{+}\right)$, potassium $\left(\mathrm{K}^{+}\right)$and calcium $\left(\mathrm{Ca}^{2+}\right)$ with time, suggesting that there was no surface saturation of the electrode during the period of desalination and (c) ion adsorption process was relatively constant for high concentration ions like sodium and calcium.
Water from well one has a TDS of $\sim 4 \mathrm{~g} / \mathrm{L}$ with an initial conductivity of $5.5 \mathrm{mS} / \mathrm{cm}$. From ICP measurements, the calcium content in well one (330 ppm) was found to be more than that of sodium (293 ppm), while the potassium content was low (10 ppm). On being passed through the CDI cell continuously for 15 minutes (without any regeneration), the solution conductivity was reduced to $\sim 3.6 \mathrm{mS} / \mathrm{cm}$, effectively a $35 \%$ reduction in TDS of the water with an electrode-specific salt adsorption capacity of $\sim 8 \mathrm{mg} / \mathrm{g}$ [Fig. 6a]. ICP analysis of the desalinated water showed that $\mathrm{Na}^{+}$ was reduced by $35 \%, \mathrm{Ca}^{2+}$ by $44 \%$, and $\mathrm{K}^{+}$by $23 \%$ following the well- established adsorption trend of higher selectivity for divalent and higher concentration ions over monovalent and low concentration ions (Hou and Huang 2013) [Fig. 6b and Table 2]. $\mathrm{Na}^{+}$ions had preferential selectivity for adsorption over $\mathrm{K}^{+}$ions although they had the same ionic charge. In cases where the magnitude of charge is the same, ions with a higher concentration, like $\mathrm{Na}{ }^{+}$in this case, will be selectively adsorbed due to a stronger driving force mediated by the concentration gradients, resulting in easier ion transport through the ACC pores (Hou and Huang 2013).

Figure $6 \mathrm{~b}$ shows the comparison of normalized ion adsorption curves for the three ions, which confirms that $\mathrm{Ca}^{2+}$ has a higher adsorption capacity as compared to the other two ions, and that the electrode surface is not saturated after the 15-minute deionization period. This was further confirmed as the first order differential plots of the ion adsorption curves showed that the slope of the tangent lines for $\mathrm{Na}^{+}$and $\mathrm{Ca}^{2+}$ were either constant $\left(\mathrm{Na}^{+}\right)$or still increasing $\left(\mathrm{Ca}^{2+}\right)$, which would not be the case if the electrode was saturated [Fig. 6c]. The absence of electrode saturation is an important aspect of the CDI operation to maximize the charge efficiency, which is expressed as a ratio of electrical charge input to ionic charge adsorbed. The charge efficiency was found to be $\sim 68 \%$, expressing the 
power efficiency of the deionization process (Huang et al. 2012; Zhao et al. 2010). Based on these results, the deionization period of further experiments was fixed at 15 minutes.

To estimate the total power and time required to bring a saline ground water sample to drinking water standards, water from well two was passed through the CDI cell in multiple deionizationregeneration cycles. The deionization was carried out for seven cycles in a repeated batch mode for $200 \mathrm{ml}$ of water from well two, where each cycle comprises a deionization period of 15 minutes followed by a regeneration period of 20 minutes. The solution conductivity was reduced from 3.2 $\mathrm{mS} / \mathrm{cm}$ to $0.84 \mathrm{mS} / \mathrm{cm}$, effectively removing $73 \%$ of the ion content from the brackish water from well two, with an average electrode salt adsorption capacity of $6.2 \mathrm{mg} / \mathrm{g}$ [Fig. 7a]. The rate of ion adsorption was determined by taking the first order differential of the normalized ion adsorption curve, plotted with respect to deionization cycles. As the adsorption function continuously reduces with time, its derivative will have a perpetual negative slope, where a high negative value indicates a high adsorption rate. Similarly, a positive slope (rising) indicates a reducing adsorption rate and a negative slope (falling) an increasing rate. As observed, the adsorption rate curves suggest that for both singly and doubly charged ions, the adsorption rate initially decreases with time to reach a steady state where the rate shows a value close to zero and then increases again when the solution ion concentration reduces further [Fig. $7 \mathrm{~b}$ ].

This trend suggests that adsorption rates and solution ion concentrations are not constant and change with each cycle. In essence, the water was successively depleted of the salt ions in each cycle, with a total $\mathrm{Na}^{+}$removal of $85 \%, \mathrm{Ca}^{2+}$ removal of $86 \%$, and $\mathrm{K}^{+}$removal of $63 \%$ [Table 3]. As the conductivity of the water sample decreased with an increasing number of deionization cycles, the power consumption also decreased [Fig. 8], showing that the power was directly related to the ionic strength of the solution being desalinated.

Thus, water with a high ion concentration will require higher power, limiting the application of CDI for low to moderate saline ground water deionization (Cohen et al. 2013; Zhao et al. 2013). Extrapolating the power consumption data from the desalinated one $\mathrm{m}^{3}$ of well two water to drinking water quality (from $3.2 \mathrm{mS} / \mathrm{cm}$ to $0.84 \mathrm{mS} / \mathrm{cm}$ ), 1 $\mathrm{kWh}$ of power would be required, excluding power consumed for pumping. This in effect would be lower than the power required for $\mathrm{RO}$ of a similar water sample. The absence of a membrane in the design, small footprint with low manufacturing costs, and chemically robust nature of the ACC electrode will further reduce the recurring costs of the system. Additionally, the low voltage and current requirements of the CDI cell as compared to RO make it more effective as a portable deionization unit for use in remote locations (Zhang et al. 2013).
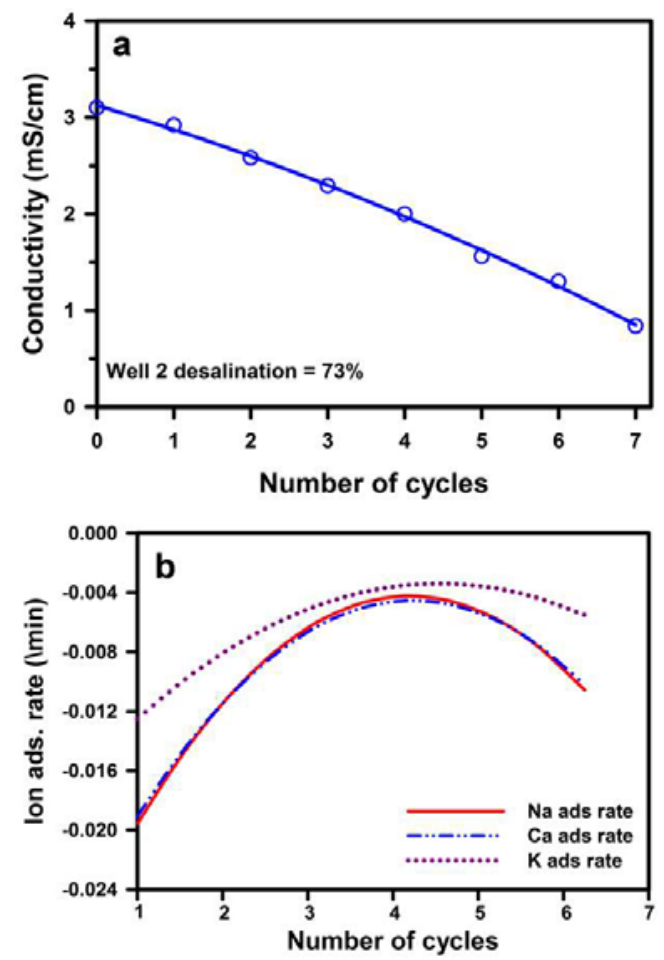

Figure 7. (a) Desalination performance of a multiple batch mode process for water from well 2, leading to $73 \%$ overall salt removal efficiency. The desalination was carried at a flow rate of $5 \mathrm{ml} / \mathrm{min}$ for 7 desalination (followed by regeneration) cycles of 15 minutes each at an applied potential of $1.6 \mathrm{~V}$ DC; (b) the ion adsorption rates for sodium, potassium and calcium increases and subsequently reduces with time, suggesting that ion removal rate varies linearly with the ion concentration in solution, with lower ion concentration leading to lower removal rates. 

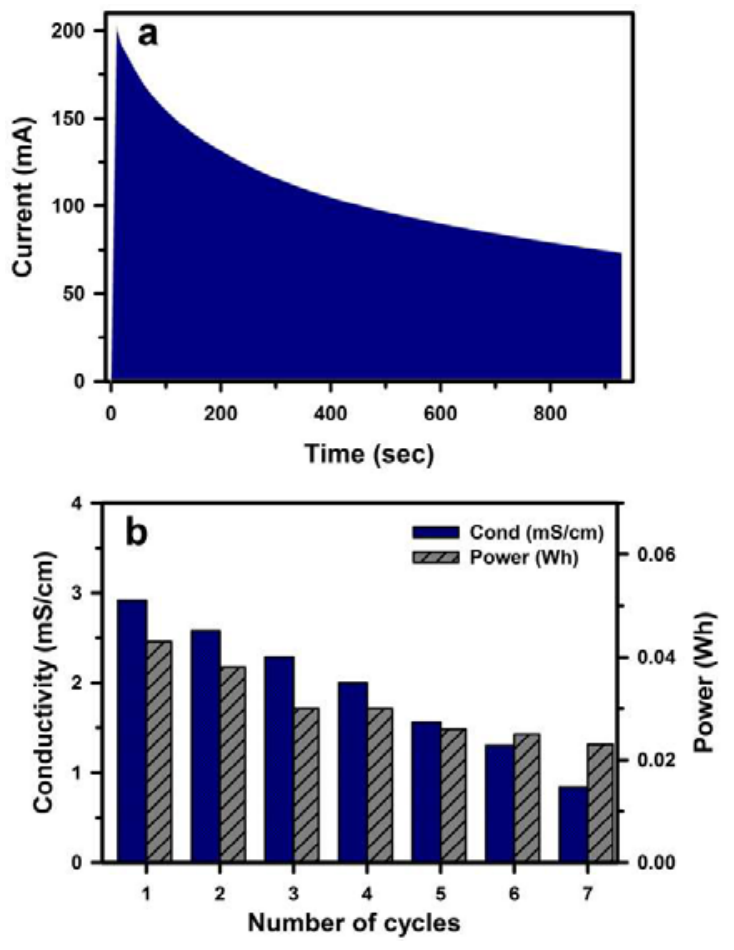

Figure 8. (a) Integration of the area under the desalination current curve for 1 cycle to calculate the total charge delivered to the CDI cell during the desalination process. This charge multiplied by the applied potential $(1.6 \mathrm{~V} \mathrm{DC})$ and divided by the time duration of the desalination cycle (15 minutes) to give the power (watt) consumption which was converted to watt-hour format; (b) graph showing the change in conductivity per desalination cycle and its associated power consumption for the desalination cycle in watt-hours, which suggests that power consumption reduces with conductivity (ion concentration).

\section{Conclusions}

The viability of the CDI device in desalinating ground water samples from the Al-Musanaah Region of Oman has been shown. The ion content and conductivity of $200 \mathrm{ml}$ of brackish water (well two) was reduced from its initial value of 3.2 $\mathrm{mS} / \mathrm{cm}$ to $0.84 \mathrm{mS} / \mathrm{cm}$, making it drinking water quality, with just $0.2 \times 10^{-3} \mathrm{kWh}$ of power consumption. It is estimated that one $\mathrm{m}^{3}$ of water from well two could be desalinated to drinking water standards using one $\mathrm{kWh}$ of power, which is lower than that required by RO. Additionally, scaling and fouling ions were shown to be efficiently removed during the process, making the $\mathrm{CDI}$ a viable option for brackish water deionization.

\section{Acknowledgments}

The authors would like to thank the Chair in Nanotechnology, The Research Council of Oman (TRC), and Sultan Qaboos University for financial support.

\section{References}

Ahmed M, Shayya W, Hoey D, Al-Handaly J (2001), Brine disposal from reverse osmosis desalination plants in oman and the united arab emirates. Desalination 133: 135-147.

Amiri M, Samiei M (2007), Enhancing permeate flux in a RO plant by controlling membrane fouling. Desalination 207: 361-369.

Antony A, Low J, Gray S, Childress A, Le-Clech P, Leslie G (2011), Scale formation and control in high pressure membrane water treatment systems: A review. Journal of Membrane Science 383: 1-16.

Biesheuvel PM, van Limpt B, van der Wal A (2009), Dynamic adsorption/desorption process model for capacitive deionization. Journal of Physical Chemistry C 113: 5636-5640.

Brasquet C, Le Cloirec P (1999), Effects of activated carbon cloth surface on organic adsorption in aqueous solutions. Use of statistical methods to describe mechanisms. Langmuir 15: 5906-5912.

Cohen I, Avraham E, Soffer A, Aurbach D (2013), Water desalination by capacitive deionization advantages limitations and modification. ECS Transactions 45: 43-59.

Farhat S, Kamel F, Jedoui Y, Kallel M (2012), The relation between the $\mathrm{RO}$ fouling membrane and the feed water quality and the pretreatment in djerba island plant. Desalination 286: 412-416.

García-Quismondo E, Santos C, Lado J, Palma J, Anderson MA (2013), Optimizing the energy efficiency of capacitive deionization reactors working under real-world conditions. Environmental Science Technology 47: 1186611872.

Gastli A, Charabi Y, Zekri S (2010), Gis-Based Assessment of combined csp electric power and seawater desalination plant for duqum - Oman. Renewable and Sustainable Energy Reviews 14: 821-827.

Ghabayen S, McKee M, Kemblowski M (2004), Characterization of uncertainties in the operation and economics of the proposed seawater desalination plant in the gaza strip. Desalination 161: 191-201. 
Ghafour E (2003), Enhancing RO system performance utilizing antiscalants. Desalination 153: 149-153.

Hassan A, Al-Sofi M, Al-Amoudi A, Jamaluddin A, Farooque A, Rowaili A, Dalvi A, Kither N, Mustafa G, Al-Tisan I (1998), A new approach to membrane and thermal seawater desalination processes using nanofiltration membranes (Part 1). Desalination 118: 35-51.

Hou CH, Huang CY (2013), A comparative study of electrosorption selectivity of ions by activated carbon electrodes in capacitive deionization. Desalination 314: 124-129.

Huang W, Zhang Y, Bao S, Song S (2013), Desalination by capacitive deionization with carbon-based materials as electrode: A review. Surface Review and Letters 20: 1330003-1330023.

Huang ZH, Wang M, Wang L, Kang F (2012), Relation between the charge efficiency of activated carbon fiber and its desalination performance. Langmuir 28: 5079-5084.

Laxman K, Myint MTZ, Al Abri M, Sathe P, Dobretsov S, Dutta J (2015), Desalination and disinfection of inland brackish ground water in a capacitive deionization cell using nanoporous activated carbon cloth electrodes. Desalination 362: 126-132.

Lee JB, Park KK, Eum HM, Lee CW (2006), Desalination of a thermal power plant wastewater by membrane capacitive deionization. Desalination 196: 125-134.

Mohamed A, Maraqa M, Handaly J, (2005), Impact of land disposal of reject brine from desalination plants on soil and groundwater. Desalination 182: 411-433.

Mossad M, Zhang W, Zou L (2013), Using capacitive deionisation for inland brackish groundwater desalination in a remote location. Desalination 308: 154-160.

Mossad M, Zou L (2013), Study of fouling and scaling in capacitive deionisation by using dissolved organic and inorganic salts. Journal of Hazardous Materials 244-245: 387-393.

Ministry of Agriculture and Fisheries (2012), Oman salinity strategy, Muscat, Oman.

Ministry of Regional Municipalities and Water Resources (2006).

Nicolaisen B (2002), Developments in membrane technology for water treatment. Desalination 153: $355-360$.

Oren Y (2008), Capacitive deionization (cdi) for desalination and water treatment - past, present and future (A review). Desalination 228: 10-29.
Porada S, Zhao R, Van der wal A, Presser V, Biesheuvel PM (2013), Review on the science and technology of water desalination by capacitive deionization. Progress in Materials Science 58: 1388-1442.

Ryoo MW, Kim JH, Seo G (2003), Role of titania incorporated on activated carbon cloth for capacitive deionization of nacl solution. Journal of Colloid Interface Science 264: 414-419.

Shim JW, Park SJ, Ryu SK (2001), Effect of modification with $\mathrm{HNO}_{3}$ and $\mathrm{NaOH}$ on metal adsorption by pitch-based activated carbon fibers. Carbon 39: 1635-1642.

Subrenat A, Baléo JN, Le Cloirec P, Blanc PE (2001), Electrical behaviour of activated carbon cloth heated by the joule effect: Desorption application. Carbon 39: 707-716.

Tzotzi C, Pahiadaki T, Yiantsios S, Karabelas A, Andritsos N (2007), A study of $\mathrm{CaCO}_{3}$ scale formation and inhibition in $\mathrm{RO}$ and $\mathrm{NF}$ membrane processes. Membrane Science 296: 171-184.

Van Der Bruggen B, Braeken L, Vandecasteele C (2002), Evaluation of parameters describing flux decline in nanofiltration of aqueous solutions containing organic compounds. Desalination 147: 281-288.

Vrouwenvelder J, Kappelhof J, Heijman S, Schippers J, Kooij D (2003), Tools for fouling diagnosis of NF and RO membranes and assessment of the fouling potential of feed water. Desalination 157: 361-365.

Welgemoed TJ, Schutte CF (2005), Capacitive deionization technology $\mathrm{y}^{\mathrm{TM}}$ : An alternative desalination solution. Desalination 183: 327-340.

Zhang W, Mossad M, Zou L (2013), A study of the long-term operation of capacitive deionisation in inland brackish water desalination. Desalination 320: 80-85.

Zhao R, Biesheuvel PM, Miedema H, Bruning $\mathrm{H}$, van der Wal A (2010), Charge efficiency: A functional tool to probe the double-layer structure inside of porous electrodes and application in the modeling of capacitive deionization. Journal of Physical Chemistry Letters 1: 205-210.

Zhao R, Porada S, Biesheuvel PM, van der Wal A (2013), Energy consumption in membrane capacitive deionization for different water recoveries and flow rates, and comparison with reverse osmosis. Desalination 330: 35-41. 